\title{
Effect of intermittent induced aeration on nitrogen removal and denitrifying-bacterial community structure in Cork and gravel vertical flow pilot- scale treatment wetlands
}

Lorena Aguilar, Ángel Gallegos, Leonardo Martín Pérez, Carlos A. Arias, Raquel Rubio, Leila Haulani, Josep García Raurich, Marc Pallarés, Joan de Pablo \& Jordi Morató

To cite this article: Lorena Aguilar, Ángel Gallegos, Leonardo Martín Pérez, Carlos A. Arias, Raquel Rubio, Leila Haulani, Josep García Raurich, Marc Pallarés, Joan de Pablo \& Jordi Morató (2021): Effect of intermittent induced aeration on nitrogen removal and denitrifying-bacterial community structure in Cork and gravel vertical flow pilot-scale treatment wetlands, Journal of Environmental Science and Health, Part A, DOI: 10.1080/10934529.2021.1967652

To link to this article: https://doi.org/10.1080/10934529.2021.1967652

\section{舟 Published online: 20 Aug 2021.}

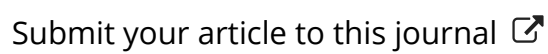

Q View related articles $\square$

View Crossmark data ¿ 


\title{
Effect of intermittent induced aeration on nitrogen removal and denitrifying- bacterial community structure in Cork and gravel vertical flow pilot-scale treatment wetlands
}

\author{
Lorena Aguilar ${ }^{\mathrm{a}}$, Ángel Gallegos ${ }^{\mathrm{a}}$, Leonardo Martín Pérez ${ }^{\mathrm{a}, \mathrm{b}}$, Carlos A. Arias ${ }^{\mathrm{c}, \mathrm{d}}$, Raquel Rubio ${ }^{\mathrm{a}}$, Leila Haulani ${ }^{\mathrm{a}}$, \\ Josep García Raurich ${ }^{\mathrm{e}}$, Marc Pallarés ${ }^{\mathrm{f}}$, Joan de Pablog ${ }^{\mathrm{g}}$, and Jordi Morató ${ }^{\mathrm{a}}$ \\ aUNESCO Chair on Sustainability, Universitat Politècnica de Catalunya, Terrassa, Spain; ${ }^{\mathrm{b}}$ Instituto de Investigaciones en Ingeniería Ambiental, \\ Química y Biotecnología Aplicada (INGEBIO-UCA, CONICET), Fac. de Química e Ingeniería del Rosario, Pontificia Universidad Católica \\ Argentina (UCA-Rosario), Rosario (Santa Fe), Argentina; ' ${ }^{\circ}$ Department of Biological Sciences, University of Aarhus, Arhus C, Denmark; ${ }^{d}$ Aarhus \\ University Centre for Water Technology WATEC, Aarhus University, Aarhus C, Denmark; ${ }^{\mathrm{e} C e n t r o ~ d e ~ I n v e s t i g a c i o ́ n ~ e n ~ S e g u r i d a d ~ y ~ C o n t r o l ~}$ \\ Alimentario (CRESCA), Depto. de Ingeniería Química, Universidad Politécnica de Cataluña-BarcelonaTech, Terrassa, Spain; ${ }^{\mathrm{f}}$ Grupo de \\ Desarrollo Empresarial, I + D+i, S.L, C/Colom, Terrassa, Spain; ${ }^{9}$ Resource Recovery and Environmental Management (R2EM), Depto. de \\ Ingeniería Química, Universidad Politécnica de Cataluña-BarcelonaTech, Barcelona, Spain
}

\begin{abstract}
In this work, we have evaluated the impact of intermittent induced aeration in total nitrogen (TN), ammonia $\left(\mathrm{NH}_{4}-\mathrm{N}\right)$ and nitrate-nitrogen $\left(\mathrm{NO}_{3}-\mathrm{N}\right)$ removal in four pilot-scale vertical flow constructed wetlands (VFCW) (two aerated two non-aerated) using cork by-product or gravel as the filter material and planted with Phragmites australis. Both aerated and non-aerated systems achieved high $\mathrm{COD}$ and $\mathrm{BOD}_{5}$ elimination rates $(\geq 90 \%)$ at the end of the 5 -month test period. However, the aerated systems presented maximal $\mathrm{COD}$ and $\mathrm{BOD}_{5}$ removal from the third month of operation onwards since air supply favored the oxidative bioprocesses occurring within the wetlands. Cork and gravel aerated VFCW also proved to be more efficient $(p<0.05)$ in $\mathrm{NO}_{3}-\mathrm{N}$ removal than the non-aerated systems and this upgraded performance was correlated with a significant higher relative abundance of the nirS gene. The aerated systems also showed a slightly improved $\mathrm{NH}_{4}-\mathrm{N}$ removal. Noticeably, cork VFCW showed higher TN removal mean values ( $35 \%)$ than gravel wetlands (27-28\%) regardless aeration. Moreover, cork VFCW showed higher relative abundance of the nosZ gene. Our results demonstrated a better nitrogen elimination for the aerated cork pilotscale VFCW, and this behavior was correlated with a higher abundance of both nirS and nosZ, two of the key functional genes involved in nitrogen metabolism.
\end{abstract}

\section{ARTICLE HISTORY}

Received 1 December 2020

Accepted 9 August 2021

\section{KEYWORDS}

Cork by-product; carbon source; nitrogen compounds removal; $\mathrm{C} / \mathrm{N}$ ratio; nirS gene; nosZ gene

\section{Introduction}

Nitrogen pollution has become a worldwide emerging concern, because of the environmental impact of nitrogen-caused water eutrophication and subsequent toxicity to aquatic organisms. Inorganic nitrogen compounds (i.e., ammonia, nitrite and nitrate) in water and wastewater are also significant in public health, agriculture, industry, and geochemistry. Moreover, nitrate $\left(\mathrm{NO}_{3}{ }^{-}\right)$is a risk to human health, especially as a possible cause of infant methemoglobinemia. ${ }^{[1]}$

On the other hand, nitrogen-containing organic compounds also play an important role in water pollution. The concentrations of these pollutants vary according to the nature of the water source. In addition, these compounds have different origins mainly agricultural, industrial and pharmaceutical, but also animal and domestic sources help to diversify and amplify the nitrogenous organic pollution. ${ }^{[2]}$ Therefore, cost-effective and environmentally friendly nitrogen pollution abatement techniques are highly desired and recommended in order to protect freshwater ecosystems, minimize eutrophication of the receiving waters, and secure biodiversity; as well as to accomplish with the current regulations such as the Water Framework Directive (Directive 2000/60/EC) and the Groundwater Directive (Directive 2006/118/EC) aiming to preserve water quality from nitrates discharges by agriculture.

Treatment wetlands (TW) are a reliable technology commonly used to treat different types of wastewater where the design intended to mimic the physico-chemical and biological processes that naturally occurs among the components of a natural wetland (i.e., vegetation, substrate, and microbial communities). ${ }^{[3]}$ Constructed wetlands technologies have also been widely used for the treatment of surface runoff, mine waters, leachates and industrial applications. They are also used for treating sewage sludges (STRBs) and can be used for full treatment of sewage (French System). ${ }^{[4-5]}$ Nevertheless, the limited oxygen transfer capacity and availability within the granular media sometimes limits aerobic treatment for effluents with a high oxygen 
demand and results in large footprint requirements or insufficient treatment. ${ }^{[6,7]}$ One of the options to increase oxygen transfer is to install aeration, thereby increasing the oxygen transfer rates. ${ }^{[8,9]}$ In such sense, an aerated TW may consist of a water-saturated bed (typically $1 \mathrm{~m}$ depth but can be deeper allowing increased $\mathrm{O}_{2}$ transfer) filled with an appropriate granular media and air diffusers installed at the bottom of the bed. The air is pumped using a low-pressure air compressor into the base of the bed so that air bubbles riseup through the water filled media void spaces, transferring $\mathrm{O}_{2}$ from the gas to the dissolved state in the process. Further, the aeration cycles can be regulated using a timer to enhance total nitrogen removal by managing aerobic and anaerobic conditions in the reactor. Moreover, different hydraulic designs and mode of operation (i.e., horizontal or vertical flow) of the TW can be used to improve treatment efficiency of highly polluted wastewaters. ${ }^{[10,11]}$ Additionally, different substrates can be selected as the filter material in TW being the granular media a key element that can influence pollutants removal efficiency from wastewater. In the last years, there have been an increasing interest for the use of recycled materials as granular media in TW to eliminate industrial waste following the concepts of sustainability and circular economy. In such sense, cork by-products have been proposed as an alternative material for organic pollutants removal because of its great adsorbent ability related to cork chemical composition. ${ }^{\text {[12-14] }}$

It has been reported that vertical flow constructed wetlands (VFCW) with intermittent aeration present high removal rates for both organic and nitrogen compounds, reducing energy and blower costs. ${ }^{[6,15-20]}$ The removal of organic substances is achieved through the interaction of physical processes (e.g., sedimentation, filtration) and microbial degradation. ${ }^{[3,21]}$

On the other hand, nitrogen removal is a microbial-governed process, where a great diversity of microorganisms related to the nitrogen cycle are involved. ${ }^{[5]}$ Simultaneous nitrification-denitrification plays a major role for nitrogen removal, being ammonium-oxidant bacteria (AOB) nitrifiers and denitrifiers the dominant microbial communities associated to such bioprocesses. ${ }^{[22-24]}$ Nitrification is carried out in aerobic conditions, whereas denitrification occurs strictly under anoxic-anaerobic conditions. ${ }^{[21,25]}$ A recent work ${ }^{[26]}$ reported that intermittent aeration in VFCW facilitates the establishment of aerobic and anaerobic conditions at the same treatment improving total nitrogen removal. However, nitrogen removal in TW is still a key problem, especially for treating low $\mathrm{C} / \mathrm{N}$ ratio wastewaters since the aerobic process removes most of the $\mathrm{C} / \mathrm{BOD}$ as well as the ammonium resulting in insufficient carbon for the subsequent growth of denitrifying bacteria. ${ }^{[24]}$ In such case, carbon supplementation in the form of organic material may be important for optimizing $\mathrm{NO}_{3}{ }^{-}$removal from waters since carbon source is the key factor that limits the growth of denitrifying bacteria and therefore denitrification. ${ }^{[1,27-29]}$

Microbial denitrification consists of several consecutive reaction steps in which $\mathrm{NO}_{3}{ }^{-}$is reduced to dinitrogen gas $\left(\mathrm{N}_{2}\right)$. The reduction of $\mathrm{NO}_{3}{ }^{-}$to nitrite $\left(\mathrm{NO}_{2}{ }^{-}\right)$can be catalyzed by both a membrane-bound nitrate reductase or a periplasmic nitrate reductase encoded by the nar $\mathrm{G}$ or the napA genes, respectively. ${ }^{[30]}$ The reduction of $\mathrm{NO}_{2}{ }^{-}$to nitric oxide (NO) is mostly catalyzed by a widely distributed cytochrome $c d 1$ nitrite reductase encoded by the nirS gene. $^{[31]}$ The last step of the denitrification pathway is catalyzed by a nitrous oxide reductase encoded by the nos $\mathrm{Z}$ gene present in the periplasm of a high number of denitrifying bacteria. ${ }^{[22]}$

Metagenomic survey of denitrification genes abundance in TW can provide information about the different denitrifying bacterial communities present within the system and also exhibits variations in denitrification activities. ${ }^{[32,33]}$. A recent study revealed a close relationship between nitrogen removal performance of an integrated VFCW with the abundance of key functional genes involved in nitrogen metabolism. Additionally, using quantitative PCR ( $q$ PCR) technology, these authors also demonstrated a link between the relative abundance of genes involved in nitrogen conversion reactions (amoA, nirS and nxrA) and increasing $\mathrm{C} / \mathrm{N}$ ratios $(2: 1,4: 1,6: 1$, and $8: 1)$ in the influent wastewater samples. ${ }^{[28]}$

Therefore, we have evaluated the effect of induced aeration in nitrogen $\left(\mathrm{NH}_{4}-\mathrm{N}, \mathrm{NO}_{3}-\mathrm{N}\right.$ and Total Nitrogen) and organic matter removal in four pilot-scale VFCW (two aerated two non-aerated) utilizing cork by-product or gravel as the filter media for comparison purposes. All four systems were operating for 5-months, with gradually increasing pollution load (organic matter and nitrogen compounds) and hydraulic and air flow load. Additionally, the relative amount of the nirS and norZ genes in the filter media was quantified by $q$ PCR with the aim to link the nitrogen removal efficiency in cork and gravel aerated and non-aerated VFCW with the abundance of key functional genes involved in nitrogen metabolism.

\section{Materials and methods}

\section{Treatment systems}

Four pilot-scale VFCW built in July 2016 within the framework of the LIFE ECORKWASTE project ("Integrated and sustainable management of cork waste generated in the cork industry", LIFE + $14 \mathrm{ENV} / \mathrm{ES} / 460$ ) were installed at the Terrassa Polytechnic Institute Campus (IPCT) of the Polytechnic University of Catalonia-BarcelonaTech (Terrassa, Barcelona, Spain). A start up and adaptation stage was carried out for 3 months (from August to October 2016) followed by a 5-month operating period (November 2016 to March 2017). The wetlands were fed individually in parallel during both startup and the steady state operation time with a synthetic wastewater (SWW) composed of $300 \mathrm{~g}$ of corn starch flour, $3 \mathrm{~L}$ of a commercial fertilizer (Mineral fertilizer NPK 6-3-6) containing 6\% total nitrogen (3.3\% potassium nitrate and $2.7 \%$ ammonium phosphate monobasic) and $150 \mathrm{~g}$ of sugar. The chemical oxygen demand (COD) of the SWW ranged from 574 to $688 \mathrm{mg} \mathrm{L}^{-1}$. The pilot-scale VFCW were built in $1 \mathrm{~m}^{3}$ IBC containers. The granular medium was divided into three layers: a $20 \mathrm{~cm}$ 
gravel $(13 \mathrm{~mm})$ drainage layer at the bottom, a $60 \mathrm{~cm}$ filtering layer in the middle and a top $10 \mathrm{~cm}$ gravel $(13 \mathrm{~mm})$ layer to prevent the material from floating. Two different materials were used as the filter medium, $5 \mathrm{~mm} \varnothing$ gravel and $7 \mathrm{~mm} \varnothing$ granulated cork, to compare their efficiency for organic matter and nitrogen removal. Cork by-product, rejected from the cork industry, was previously washed before being placed as the filter media. The four pilot-scale VFCW were planted with Phragmites australis at a density of 4 plants per $\mathrm{m}^{2}$. A pulse loading scheme to feed the unsaturated vertical flow systems was established for two of the non-aerated pilots, whereas the other two systems were operated in an aerated vertical saturated flow to compare the effect of induced aeration on pollutants elimination. A pressurized aeration system was installed at the bottom of the beds at a density enough to allow an equal distribution of atmospheric air to the filter medium at a constant rate of $30 \mathrm{~L} \mathrm{~min}^{-1}$. Briefly, this system consisted of a diaphragm blower (Bibus JDK-50) connected to a $50 \mathrm{~mm} \varnothing$ PVC pipe, discharging into 7 agricultural irrigation pipes $(32 \mathrm{~mm}$ diameter), with drip irrigation emitters every $10 \mathrm{~cm}$. A summary of the different conditions established for the four pilot-scale VFCW are listed in Table 1.

\section{Hydraulic load and pollutant load}

The sizing of the TW was done with the first order model PKC*, according to Kadlec \& Wallace. ${ }^{[34]}$ The systems were designed considering an organic load rate that does not limit the microbial growth. The influent SWW was prepared in a $1000 \mathrm{~L}$ tank and from it pumped to individual tanks upstream of each wetland. A series of pressurized pipes were installed to homogeneously distribute the loading of SWW onto the surface of the wetlands. Effluent water samples were received in independent outlet tanks for each pilot, and from them collected for further analysis (Figure 1).

During the 5-month wetland trial, both the hydraulic load and the pollutant load $\left(\mathrm{COD}, \mathrm{BOD}_{5}, \mathrm{TN}, \mathrm{NO}_{3}-\mathrm{N}\right.$, and $\mathrm{NH}_{4}-\mathrm{N}$ ) were increased each month up to a desired maximal operational condition as described in Table 2 and Table 3. This progressive increase allowed the gradual adaptation of the wetland biofilm to the increasing hydraulic load, pollutant concentration, and aeration conditions. The wastewater was distributed across the surface of each pilot wetland at a rate of $25 \mathrm{~L}$ pulses, starting with two pulses per day (i.e., $50 \mathrm{~L} \mathrm{~d}^{-1}$ ) and progressively increasing to reach $200 \mathrm{~L} \mathrm{~d}^{-1}$ (Table 2). Atmospheric air was introduced only to the aerated systems (named VF3-CA and VF4-GA; see Figure 1) during the loading time at an airflow of $0.5 \mathrm{~L}$ $\mathrm{min}^{-1}$. The inflow rate and the aeration time were progressively increased from $1.5 \mathrm{~h} \mathrm{~d}^{-1}$ to $6.5 \mathrm{~h} \mathrm{~d}^{-1}$ (Table 3).

\section{Sampling}

The monitoring of pilot scale wetlands was routinely carried out throughout the operational period (from November 2016 to March 2017). The sampling campaigns took place the third week of each month by collecting water samples
Table 1. Granular media and operation conditions used at the VFCW systems.

\begin{tabular}{llcll}
\hline Pilot wetland & Filter medium & $\emptyset(\mathrm{mm})$ & Air introduced & Water flow \\
\hline VF1-CnA & Cork & 7 & No & Unsaturated \\
VF2-GnA & Gravel & 5 & No & Unsaturated \\
VF3-CA & Cork & 7 & Yes & Saturated \\
VF4-GA & Gravel & 5 & Yes & Saturated \\
\hline
\end{tabular}

for three consecutive days at the SWW mixing tank, the pilots' influent, and from the effluent collection tanks receiving treated flows from each individual wetland. Samples were collected in $500 \mathrm{~mL}$ sterile plastic bottles and transported under refrigeration to the laboratory for physicochemical parameters analysis.

For the microbiological analysis composite samples were taken from three different points of each wetland. The material was extracted from the filter medium at a $20 \mathrm{~cm}$ depth. Gravel (100 g) and cork (25g) samples were collected at the end of the experimental time and poured into $500 \mathrm{~mL}$ sterile glass bottles containing $250 \mathrm{~mL}$ of PBS $(130 \mathrm{mM}$ $\left.\mathrm{NaCl}, 2.7 \mathrm{mM} \mathrm{KCl}, 10 \mathrm{mM} \mathrm{KH} \mathrm{PO}_{4} / \mathrm{Na}_{2} \mathrm{HPO}_{4}, \mathrm{pH} 7.4\right)$ to avoid drying and lysis of the bacterial cells. ${ }^{[13]}$ The bottles were stored at $4{ }^{\circ} \mathrm{C}$ to preserve the biofilm. A total of 5 composite samples were collected for each pilotscale VFCW.

\section{Physicochemical parameters}

Water temperature, dissolved oxygen $\left(\mathrm{O}_{2}\right)$ and $\mathrm{pH}$ were measured in-situ at the filter media layer during the last loading cycle, using commercially available calibrated electrodes (Hach Lange $\mathrm{BmbH}$, Barcelona). In all cases, aeration was active to measure the $\mathrm{O}_{2}$ difference between the aerated and the non-aerated pilots. Additionally, COD (APHA 5200 B), $\mathrm{BOD}_{5}$ (APHA $5210 \mathrm{~B}$ ), total nitrogen (TKN Kjeldhal method), nitrate $\left(\mathrm{NO}_{3}-\mathrm{N}\right)$ content (APHA $\left.4500-\mathrm{NO}_{3} \mathrm{~F}\right)$ and ammonia nitrogen $\left(\mathrm{NH}_{4}-\mathrm{N}\right)$ (APHA $\left.4500-\mathrm{NH}_{3} \mathrm{D}\right)$ concentration were analyzed once the samples reached the laboratory (less than one hour after sampling). ${ }^{[35]}$

\section{Microbial community analyses}

Real-time quantitative PCR ( $q$ PCR) assays from DNA attached to the filter media were performed to assess bacterial load using the 16S rRNA gene as the molecular marker, and to quantify two of the key functional genes for denitrification (nirS and nosZ). The nirS gene codifies a nitrite reductase enzyme responsible for the conversion of $\mathrm{NO}_{2}{ }^{-}$to NO. On the other hand, the nos $\mathrm{Z}$ gene codifies a nitrous oxide reductase enzyme responsible for the conversion of nitrous oxide $\mathrm{N}_{2} \mathrm{O}$ to $\mathrm{N}_{2}{ }^{[22]}$

\section{DNA extraction}

Biofilm DNA was obtained as described by Aguilar et al. ${ }^{[14]}$ Briefly, filter media samples (i.e., cork or gravel) were sonicated for $3 \mathrm{~min}$ in an ultrasonic bath (150 W-6L, JP Selecta, Barcelona, Spain). The supernatant was then centrifuged (4000 rpm, $8 \mathrm{~min}$.) using a Medifriger centrifuge (BL-S, JP 


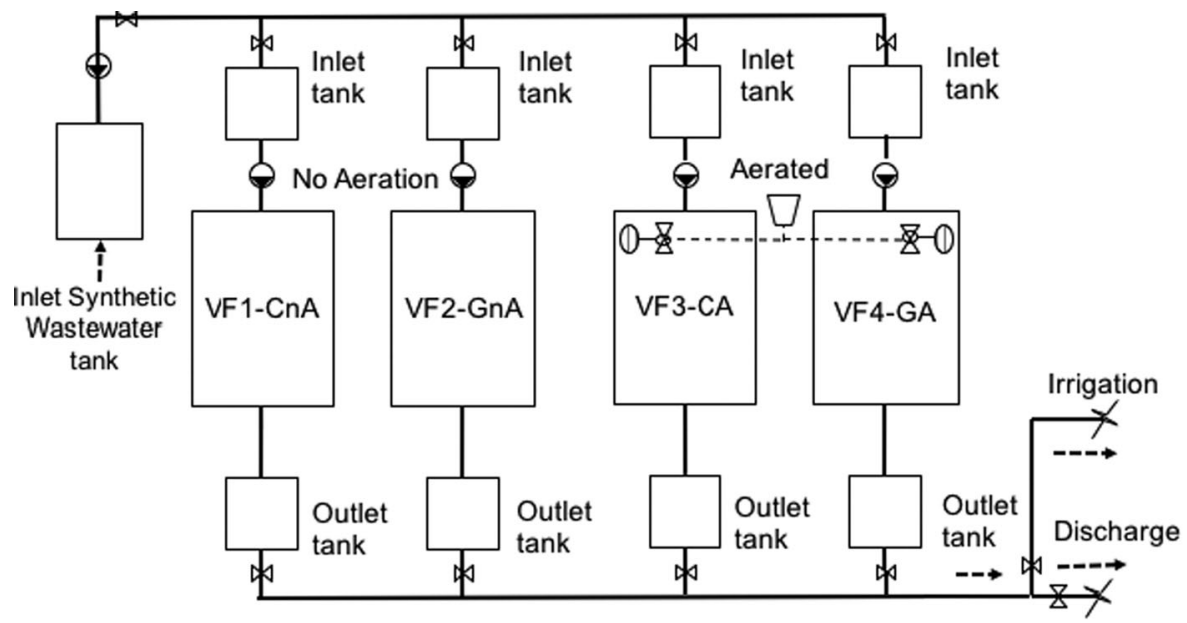

Figure 1. General scheme of operation of the four pilot-scale VFCW studied at the present work.

Table 2. Variation of the hydraulic load and input pollutant load during wetlands operation period.

\begin{tabular}{|c|c|c|c|c|c|c|c|c|c|c|}
\hline Month & $\begin{array}{c}\text { Inflow } \\
\text { rate } \\
\left(\mathrm{L} \mathrm{d}^{-1}\right)\end{array}$ & $\begin{array}{l}\text { Aeration } \\
\text { time }\left(\mathrm{h} \mathrm{d}^{-1}\right)\end{array}$ & $\begin{array}{c}\mathrm{O}_{2} \\
\left(\mathrm{mg} \mathrm{L}^{-1}\right)\end{array}$ & $\begin{array}{c}\text { COD } \\
\left(\mathrm{g} \mathrm{m}^{-2} \mathrm{~d}^{-1}\right)\end{array}$ & $\begin{array}{c}\mathrm{BOD}_{5} \\
\left(\mathrm{~g} \mathrm{~m}^{-2} \mathrm{~d}^{-1}\right)\end{array}$ & $\begin{array}{c}\mathrm{NH}_{4}-\mathrm{N} \\
\left(\mathrm{g} \mathrm{m}^{-2} \mathrm{~d}^{-1}\right)\end{array}$ & $\begin{array}{c}\mathrm{NO}_{3}-\mathrm{N} \\
\left(\mathrm{g} \mathrm{m}^{-2} \mathrm{~d}^{-1}\right)\end{array}$ & $\begin{array}{c}\text { TN } \\
\left(\mathrm{g} \mathrm{m}^{-2} \mathrm{~d}^{-1}\right) \\
\end{array}$ & $\mathrm{pH}$ & $\mathrm{T}\left({ }^{\circ} \mathrm{C}\right)$ \\
\hline Nov & 50 & 1.5 & $5.9 \pm 0.5$ & $11.2 \pm 1.1$ & $5.8 \pm 0.8$ & $5.0 \pm 0.1$ & $1.4 \pm 0.1$ & $10.5 \pm 1.2$ & $6.7 \pm 0.2$ & $12.0 \pm 1.6$ \\
\hline Feb & 150 & 4.5 & $6.7 \pm 1.0$ & $51.5 \pm 0.8$ & $38.6 \pm 5.6$ & $32.0 \pm 0.4$ & $6.4 \pm 1.1$ & $51.6 \pm 2.3$ & $6.7 \pm 0.1$ & $15.8 \pm 0.9$ \\
\hline Mar & 200 & 6.5 & $5.4 \pm 0.2$ & $73.6 \pm 1.6$ & $58.3 \pm 8.4$ & $59.0 \pm 3.3$ & $10.7 \pm 1.6$ & $73.1 \pm 6.2$ & $7.0 \pm 0.1$ & $17.5 \pm 0.7$ \\
\hline
\end{tabular}

$\mathrm{O}_{2}=$ dissolved oxygen; $\mathrm{COD}=$ chemical oxygen demand; $\mathrm{BOD}_{5}=$ biological oxygen demand; $\mathrm{NH} 4-\mathrm{N}$, ammonia nitrogen; $\mathrm{NO}_{3}-\mathrm{N}=$ nitrate nitrogen; $\mathrm{TN}^{-}$total nitrogen. Data corresponds to mean values \pm S.D. of three independent measurements $(n=3)$.

Table 3. Operational conditions used in the aerated pilot-scale treatment wetlands.

\begin{tabular}{lccccc}
\hline Month & $\begin{array}{c}\text { Inflow rate } \\
\left(\mathrm{L} \mathrm{d}^{-1}\right)\end{array}$ & $\begin{array}{c}\text { Pulses /day } \\
(25 \mathrm{~L})\end{array}$ & $\begin{array}{c}\text { Pulse } \\
\text { time }(\mathrm{min})\end{array}$ & $\begin{array}{c}\text { Aeration time } \\
\left(\mathrm{h} \mathrm{d}^{-1}\right)\end{array}$ & $\begin{array}{c}\text { Air } \\
\text { flow } \\
\left(\mathrm{L} \mathrm{min}^{-1}\right)\end{array}$ \\
\hline Nov & 50 & 2 & 45 & 1.5 & 0.5 \\
Dec & 75 & 3 & & 2.0 & \\
Jan & 100 & 4 & & 3.0 & \\
Feb & 150 & 6 & & 4.5 & \\
Mar & 200 & 8 & 6.5 & \\
\hline
\end{tabular}

Selecta, Barcelona, Spain) to concentrate the detached cells. ${ }^{[36]}$ DNA extraction was performed using the DNeasy ${ }^{\circledR}$ Power Soil Kit (Qiagen, Oslo, Norway) according to the manufacturer's instructions. The concentration and the purity of the obtained DNAs were calculated from the ratio between the absorbance readings at $260 \mathrm{~nm}\left(\mathrm{~A}_{260}\right)$ and $280 \mathrm{~nm}\left(\mathrm{~A}_{280}\right)$ registered using a NanoDrop® UV-Vis spectrophotometer (ND-1000, ThermoFisher, Wilmington, DE, USA). Finally, DNA extracts were conserved at $-20^{\circ} \mathrm{C}$ until further use.

\section{$\mathbf{q} P C R$}

DNA copy number standards were created for $q \mathrm{PCR}$ using Escherichia coli (NCTC 9001), Pseudomonas aeruginosa (CECT 110), and Ralstonia eutropha (Cupriavidus necator DSM 545). ${ }^{[22]}$ DNA was extracted from overnight cultures of each strain grown in Tryptic Soy Broth (TSB, Sigma Aldrich, St. Louis, MO, USA) at $37^{\circ} \mathrm{C}$ using the v-DNA reagent (GenIUL, Terrassa, Spain). A conventional PCR amplification was first performed with the Horse-Power ${ }^{\mathrm{TM}}$
Taq DNA Polymerase mix (Canvax Biotech S.L., Córdoba, Spain) using the set of primers and cycling program described in. ${ }^{[14]}$ The PCR was followed by an agarose gel electrophoresis and purification of the PCR products using the Illustra $^{\mathrm{TM}} \mathrm{GFX}^{\mathrm{TM}}$ PCR and Gel Band Purification Kit (GE Healthcare, Chicago, IL, USA) according to manufacturer's instructions. Finally, the number of amplicons per gene was calculated from the $\mathrm{A}_{260}$ value and further used to construct the standard curves using diluted samples (from $10^{10}$ to $\left.10^{1}\right)$. Quantification of $16 \mathrm{~S}$ rRNA, nirS and nosZ genes was performed in a LightCycler 1.5 PCR system (Roche Applied Science, Mannheim, Germany) using EvaGreen ${ }^{\circledR}$-based detection $\left(5 \times\right.$ HOT FIREPol ${ }^{\circledR}$ EvaGreen $\AA$ $q$ PCR Mix Plus, Solis BioDyne, Tartu, Estonia) and verified according to Pérez et al. ${ }^{[37]}$ All standard curves showed high correlation efficiencies $\left(\mathrm{r}^{2}>0.98\right)$ and similar slopes.

\section{Statistical analysis}

Statistical analyses were performed using the SigmaStat 3.5 program (Systat Software Inc., San Jose, CA, USA). The Shapiro-Wilk and Levene tests were carried out to appraise data normality and homogeneity, respectively. The analysis of variance (ANOVA) test was used to compare effluent physicochemical parameters, nitrogen compounds (TN, $\mathrm{NO}_{3}-\mathrm{N}$ and $\mathrm{NH}_{4}-\mathrm{N}$ ) and organic matter removal (COD and $\mathrm{BOD}_{5}$ ) between VFCW. Tukey's honestly significant difference post hoc test was applied when the difference in the measured values between treatments was different $(p<0.05)$. 
Table 4. Evolution of water temperature $(\mathrm{T}), \mathrm{pH}$ and dissolved oxygen $\left(\mathrm{O}_{2}\right)$ from influent and effluent water samples at the different pilot-scale VFCW under study.

\begin{tabular}{llllll}
\hline & Inlet & VF1-CnA & VF2-GnA & VF3-CA & VF4-GA \\
Month & T $\left({ }^{\circ} C\right)$ & & & \\
\hline Nov & $12.0 \pm 1.6^{\mathrm{a}}$ & $12.5 \pm 1.0^{\mathrm{a}}$ & $12.7 \pm 0.9^{\mathrm{a}}$ & $11.6 \pm 0.8^{\mathrm{a}}$ & $11.7 \pm 0.8^{\mathrm{a}}$ \\
Dec & $14.3 \pm 1.5^{\mathrm{a}}$ & $10.1 \pm 1.6^{\mathrm{b}}$ & $9.8 \pm 1.2^{\mathrm{b}}$ & $10.1 \pm 0.2^{\mathrm{b}}$ & $11.5 \pm 1.4^{\mathrm{b}}$ \\
Jan & $9.5 \pm 0.7^{\mathrm{a}}$ & $7.8 \pm 0.3^{\mathrm{b}}$ & $7.7 \pm 0.7^{\mathrm{b}}$ & $7.8 \pm 0.4^{\mathrm{b}}$ & $8.2 \pm 0.5^{\mathrm{b}}$ \\
Feb & $15.8 \pm 0.9^{\mathrm{a}}$ & $16.4 \pm 1.9^{\mathrm{a}}$ & $16.6 \pm 2.2^{\mathrm{a}}$ & $15.9 \pm 1.9^{\mathrm{a}}$ & $15.7 \pm 1.7^{\mathrm{a}}$ \\
Mar & $17.5 \pm 0.7^{\mathrm{a}}$ & $19.8 \pm 1.9^{\mathrm{a}}$ & $19.3 \pm 2.0^{\mathrm{a}}$ & $19.4 \pm 1.9^{\mathrm{a}}$ & $19.4 \pm 2.8^{\mathrm{a}}$ \\
& $\mathrm{pH}$ & & & & \\
Nov & $6.7 \pm 0.2^{\mathrm{a}}$ & $6.4 \pm 0.2^{\mathrm{a}}$ & $6.6 \pm 0.3^{\mathrm{a}}$ & $6.5 \pm 0.2^{\mathrm{a}}$ & $6.6 \pm 0.3^{\mathrm{a}}$ \\
Dec & $6.7 \pm 0.1^{\mathrm{a}}$ & $6.9 \pm 0.1^{\mathrm{ab}}$ & $7.1 \pm 0.1^{\mathrm{b}}$ & $7.0 \pm 0.1^{\mathrm{b}}$ & $6.9 \pm 0.1^{\mathrm{b}}$ \\
Jan & $7.1 \pm 0.2^{\mathrm{a}}$ & $7.0 \pm 0.2^{\mathrm{a}}$ & $7.2 \pm 0.2^{\mathrm{a}}$ & $7.3 \pm 0.1^{\mathrm{a}}$ & $7.4 \pm 0.3^{\mathrm{a}}$ \\
Feb & $6.7 \pm 0.1^{\mathrm{a}}$ & $6.7 \pm 0.1^{\mathrm{a}}$ & $6.8 \pm 0.1^{\mathrm{a}}$ & $6.8 \pm 0.1^{\mathrm{a}}$ & $7.1 \pm 0.1^{\mathrm{b}}$ \\
Mar & $7.0 \pm 0.1^{\mathrm{a}}$ & $7.0 \pm 0.1^{\mathrm{a}}$ & $7.1 \pm 0.1^{\mathrm{a}}$ & $7.3 \pm 0.1^{\mathrm{b}}$ & $7.2 \pm 0.1^{\mathrm{ab}}$ \\
& $\mathrm{O}_{2}\left(\mathrm{mg} \mathrm{L}^{-1}\right)$ & & & \\
Nov & $5.9 \pm 0.5^{\mathrm{a}}$ & $6.9 \pm 0.4^{\mathrm{ab}}$ & $8.3 \pm 1.1^{\mathrm{b}}$ & $8.9 \pm 1.1^{\mathrm{b}}$ & $8.8 \pm 0.5^{\mathrm{b}}$ \\
Dec & $5.6 \pm 0.2^{\mathrm{a}}$ & $4.9 \pm 0.8^{\mathrm{ab}}$ & $5.4 \pm 0.8^{\mathrm{a}}$ & $3.6 \pm 0.1^{\mathrm{b}}$ & $3.6 \pm 0.3^{\mathrm{b}}$ \\
Jan & $7.5 \pm 1.5^{\mathrm{a}}$ & $6.3 \pm 0.8^{\mathrm{ab}}$ & $6.7 \pm 1.1^{\mathrm{ab}}$ & $4.9 \pm 0.9^{\mathrm{bc}}$ & $4.0 \pm 0.8^{\mathrm{c}}$ \\
Feb & $6.7 \pm 1.0^{\mathrm{a}}$ & $5.8 \pm 1.2^{\mathrm{a}}$ & $6.0 \pm 0.7^{\mathrm{a}}$ & $4.5 \pm 0.9^{\mathrm{a}}$ & $4.4 \pm 1.4^{\mathrm{a}}$ \\
Mar & $5.4 \pm 0.2^{\mathrm{a}}$ & $4.6 \pm 0.6^{\mathrm{ab}}$ & $4.2 \pm 0.9^{\mathrm{ab}}$ & $3.6 \pm 0.5^{\mathrm{b}}$ & $4.4 \pm 0.1^{\mathrm{b}}$ \\
\hline Data & &
\end{tabular}

Data corresponds to mean values \pm S.D. of three independent measurements $(n=3)$. Values with different letters in the same line are significantly different $(p<0.05)$; e.g., "a" and " $b$ " are statistically different from each other but not from "ab".

\section{Results and discussion}

\section{Organic matter removal efficiency}

Water samples from the VFCW under study were taken from November 2016 to March 2017. During the 5-month period operation inlet water temperature varied from $9.5 \pm 0.7^{\circ} \mathrm{C}$ in the coldest month (January) to $17.5 \pm 0.7^{\circ} \mathrm{C}$ in the last campaign (March). This seasonal temperature fluctuation accordingly affected the water temperature inside the wetlands (Table 4); however, these variations were not statistically different between all four pilot systems. In addition, the $\mathrm{pH}$ of the influent and effluent water samples did not considerably change during the studied period in all VFCW, varying around the neutrality between $6.4 \pm 0.2^{\circ} \mathrm{C}$ to $7.4 \pm 0.3{ }^{\circ} \mathrm{C}$ (Table 4). Moreover, dissolved oxygen $\left(\mathrm{O}_{2}\right)$ concentration measurements at the influent and effluent water samples were rather similar along the assay. All three factors (i.e., temperature, $\mathrm{O}_{2}$, and acidity/alkalinity) are important for microbial growth and for nitrification-denitrification. ${ }^{[38,39]}$ Additionally, $\mathrm{O}_{2}$ concentration is also a crucial factor influencing organic matter removal during wastewater treatment in VFCW. ${ }^{[27]}$

All studied systems were highly effective to improve effluent water quality once an appropriate microbiological activity was reached (i.e., after 1-2 month of operation) considered to be a startup acclimatization period. However, during the first sampling campaign a significant $(p<0,05)$ $\mathrm{BOD}_{5}$ removal capability was observed in the non-aerated gravel wetland (VF2-GnA) (Figure 2). This difference may be related with a more effective microbial attachment to the fine gravel respect to the cork. This concurs with other studies reporting that the type of substrate can influence microbial communities' structure and composition within TW. For example, Vacca et al. ${ }^{[40]}$ reported differences on rhizospheral microbial populations depending on filter material (expanded clay and sand), while Calheiros et al. ${ }^{[41]}$ observed that bacterial richness and community structure was affected
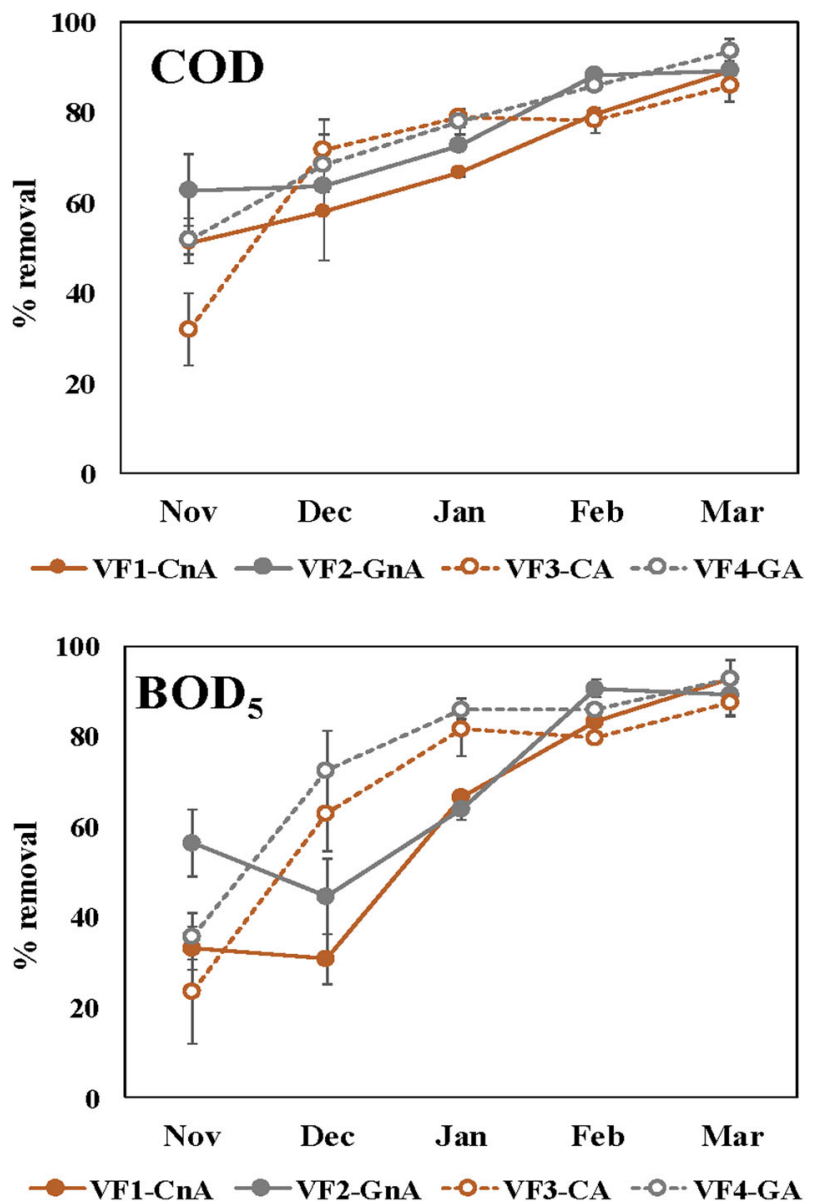

Figure 2. Evolution of $\mathrm{COD}$ and $\mathrm{BOD}_{5}$ removal efficiency in aerated $(\mathrm{A})$ and non- aerated $(\mathrm{nA})$ cork $(\mathrm{C})$ or gravel $(\mathrm{G})$ pilot-scale VFCW.

by the use of expanded clay aggregates or fine gravel. In addition, $\mathrm{Li}$ et al. ${ }^{[42]}$ compared the microbial assemblages in eight types of filter media (steel lag, bio-ceramic, ceramic, gravel, vermiculite, shale, anthracite and zeolites) concluding that significant differences in the bacterial population occurs among the different materials. More recently, Aguilar et al. ${ }^{[14]}$ reported differences in the microbial composition within a hybrid TW using cork or gravel as substrate.

On the other hand, aeration could also negatively affect microbial attachment in the aerated systems (i.e., VF3-CA and VF4-GA) during the first month of operation since air pressure may detach some bacteria during biofilm assemblage at the stabilization period.

Additionally, during the first month of VF1-CnA and VF3-CA operation a brown water color was observed in the effluent of both cork pilot-scale wetlands, due to the washing and leaching from of the cork but decreased along time. Therefore, this singularity of the filter material could also have negative affected to the establishment of an active microbial community at the cork systems during the earliest period of operation. Although differences in the microbial community structure due to the filter material may occur, all VFCW were highly effective for organic matter removal $\left(\mathrm{COD}\right.$ and $\left.\mathrm{BOD}_{5}\right)$ at the end of the experimental time (Figure 2)

As can be seen in Figure 2, a rapid increase in $\mathrm{BOD}_{5}$ removal was observed for the two aerated systems (VF3-CA 
Table 5. Physicochemical characteristics of effluent water samples at the last sampling campaign.

\begin{tabular}{|c|c|c|c|c|}
\hline \multirow{2}{*}{$\begin{array}{l}\text { Parameter } \\
\left(\mathrm{g} \mathrm{m}^{-2} \mathrm{~d}^{-1}\right)\end{array}$} & \multicolumn{4}{|c|}{ Maximal removal efficiency (\%) } \\
\hline & VF1-CnA & VF2-GnA & VF3-CA & VF4-GA \\
\hline COD & $89.1 \pm 2.4^{a}$ & $89.4 \pm 2.9^{a}$ & $86.0 \pm 3.5^{a}$ & $93.6 \pm 2.6^{\mathrm{a}}$ \\
\hline $\mathrm{BOD}_{5}$ & $91.8 \pm 3.9^{a}$ & $89.3 \pm 4.6^{\mathrm{a}}$ & $87.7 \pm 3.1^{\mathrm{a}}$ & $92.4 \pm 4.1^{\mathrm{a}}$ \\
\hline TN & $35.0 \pm 6.7^{\mathrm{a}}$ & $26.9 \pm 9.5^{\mathrm{a}}$ & $34.9 \pm 9.0^{\mathrm{a}}$ & $28.3 \pm 5.1^{\mathrm{a}}$ \\
\hline $\mathrm{NH}_{4}-\mathrm{N}$ & $54.2 \pm 2.9^{\mathrm{a}}$ & $52.3 \pm 4.1^{\mathrm{a}}$ & $58.6 \pm 4.9^{\mathrm{a}}$ & $60.1 \pm 5.2^{\mathrm{a}}$ \\
\hline $\mathrm{NO}_{3}-\mathrm{N}$ & $36.8 \pm 9.1^{\mathrm{a}}$ & $38.1 \pm 3.4^{\mathrm{a}}$ & $57.4 \pm 7.1^{b}$ & $50.1 \pm 6.3^{b}$ \\
\hline
\end{tabular}

Data corresponds to mean values \pm S.D. of three independent measurements $(n=3)$. Values with different letters in the same line are significantly different $(p<0.05)$

and VF4-GA) reaching a maximum performance from the third month of operation onwards (i.e., February) in contrast to the unaerated wetlands (VF1-CnA and VF2-GnA). These results agreed with previously reported data describing that intermittent aeration supplies the oxygen necessary to improve the removal of organic matter in the saturated VFCW. ${ }^{[4,6,16,36]}$ However, at the last sampling campaign (i.e., March) no statistically significant differences were observed for $\mathrm{COD}$ and $\mathrm{BOD}_{5}$ removal between the aerated and the non-aerated VFCW.

As can be seen in Table 5, high COD and $\mathrm{BOD}_{5}$ removal rates ranging from $89.1 \pm 2.4 \%$ to $93.6 \pm 2.6$ and $87.7 \pm 3.1$ to $92.4 \pm 4.1 \%$, respectively were achieved for the four systems analyzed (both aerated and non-aerated pilots). Notably, although cork waste has been suggested as a suitable adsorbent material for organic pollutants due to its suberin content (among other structural components), ${ }^{[12]}$ the presented results are one of the first describing high removal rates $(\sim 90 \%)$ for organic compounds in cork VFCW.

\section{Nitrogen removal efficiency}

Figure 3 shows nitrogen compounds evolution from VFCW influent and effluent water samples during the 5-month of systems operation. As it can be seen, with the increasing of the nitrogen load in the inlet, the concentrations for $\mathrm{NH}_{4}-\mathrm{N}, \mathrm{NO}_{3}-$ $\mathrm{N}$ and $\mathrm{TN}$ at the treated water also increased. No significant improvement in nitrogen removal was expected to occur with the increase in the organic load of the inlet water since $\mathrm{C} / \mathrm{N}$ ratio (1.5:1) at the influent remained rather constant along the assay and this ratio was lower than the optimal suggested for an effective nitrification $(\mathrm{C} / \mathrm{N} \geq 5: 1){ }^{[28,29]}$ In any case, nitrogen compounds values at the effluent were always lower than at the inlet water from all the treatment systems evaluated, with the exception of the $\mathrm{NH}_{4}-\mathrm{N}$ values obtained for the first sampling campaign (i.e., November). This result may be related with a low number of bacteria responsible for nitrification at the earliest established biofilm.

Nitrification constitutes a two-step process wherein ammonia is first oxidized to $\mathrm{NO}_{2}^{-}$by ammonia-oxidizing bacteria (AOB), followed by the oxidation of $\mathrm{NO}_{2}^{-}$to $\mathrm{NO}_{3}{ }^{-}$ by ubiquitous nitrite-oxidizing microorganisms. Bacteria responsible for nitrification are mostly chemolithoautotrophic microorganisms. AOB belong to the genera Nitrosomonas and Nitrosococcus, whereas nitrite-oxidizing bacteria belong to the genera Nitrobacter and Nitrospina. ${ }^{[43]}$ As expected, during wetlands continuous operation and with
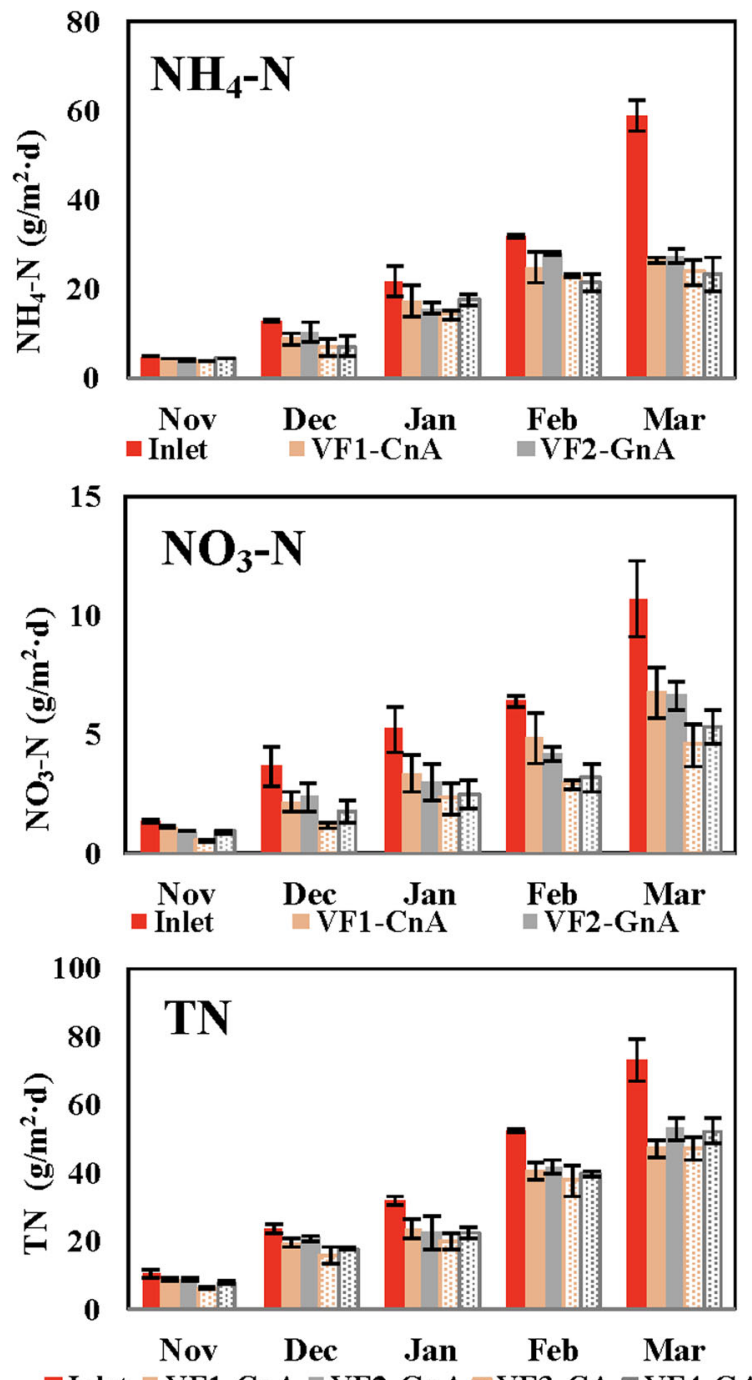

Inlet $\square$ VF1-CnA $\square$ VF2-GnA $₫$ VF3-CA $₫$ VF4-GA

Figure 3. Inlet and effluent results of $\mathrm{TN}_{1} \mathrm{NH}_{4}-\mathrm{N}$ and $\mathrm{NO}_{3}-\mathrm{N}$ at the non-aerated $(\mathrm{nA})$ and aerated (A) VFCW filled with cork (C) or gravel (G) as the granular media.

the increase in the $\mathrm{NH}_{4}-\mathrm{N}$ load at the inlet water, a greater nitrifying community structure was established in all four pilot-scale TW systems in the form of attached biofilm. Accordingly, at the last sampling campaign (i.e., March), maximal $\mathrm{NH}_{4}-\mathrm{N}$ removal rates ranging between 50-60\% were achieved in all the studied systems (Figure 3, Table 5). In addition, no significant changes were measured in the nitrifying function at the four VFCW in response to the different filter media (i.e., cork or gravel) or aeration condition.

Princic et al. ${ }^{[44]}$ reported shifts in nitrifying community structure and function in response to different $\mathrm{NH}_{4}-\mathrm{N}$ concentrations, $\mathrm{pH}$ values, and $\mathrm{O}_{2}$ concentrations in experimental reactors inoculated with nitrifying bacteria from a wastewater treatment plant. At the present study, all these parameters were relatively consistent in the influent and effluent of the four VFCW along the experimental time (see Table 2 and Table 4). Therefore, given the relatively consistent $\mathrm{pH}$, dissolve oxygen and temperature across the four pilot systems we hypothesized that microbial growth and establishment was of a similar density in each system. 
On the other hand, Bellucci et al. ${ }^{[45]}$ tested the effect of aeration on nitrification by correlating $\mathrm{NH}_{4}-\mathrm{N}$ oxidation rates with the structure and abundance of the AOB community in lab-scale reactors demonstrating that complete nitrification can be also achieved at low aeration. In addition, these authors revealed that the AOB community in the lowoxygenated systems was a subset of the community in the high-oxygenated reactors. In both such configurations, the dominant species belonged to the Nitrosomonas lineage, a proteobacterial ammonia oxidizer which can nitrify even growing under oxygen limitation. ${ }^{[46]}$ Related to this, we have recently found a similar occurrence of Nitrosomonas, Nitrosococcus, Nitrobacter and Nitrospira (all key microorganisms involve in the nitrogen cycle) in cork and gravel non-aerated TW treating nitrogen polluted groundwater. ${ }^{[14]}$ Therefore, it is unsurprising that similar $\mathrm{NH}_{4}-\mathrm{N}$ removal rates for aerated and non-aerated cork and gravel pilot-scale VFCW studied at the present work may occur. However, interestingly, both aerated systems (VF3-CA and VF4-GA) presented a milder improve in $\mathrm{NH}_{4}-\mathrm{N}$ removal ability than the non-aerated wetlands (VF1-CnA and VF2-GnA) at the maximal aeration time of $6.5 \mathrm{~h} \mathrm{~d}^{-1}$ corresponding to the last sampling campaign (i.e., March), even though this difference was not statistically significant between unsaturated (with no aeration) vs saturated (with aeration) because both modes of operation seemed to achieve similar DO concentrations (Figure 3, Table 5).

Otherwise, $\mathrm{NO}_{3}-\mathrm{N}$ removal showed a significant increase $(p<0.05)$ in the aerated systems in respect to the non-aerated wetlands along the experimental time, and this behavior seemed to be independent on the filter type (Figure 3). Some studies have reported that nitrification-denitrification process and thus nitrogen removal is enhanced in VFCW when the operation periods (aerobic-anaerobic conditions) in the wetland bed are controlled by intermittent induced aeration. ${ }^{[4,26]}$ Our results partially agree with such observations since both aerated systems (i.e., VF3-CA and VF4-GA) showed $\mathrm{NO}_{3}-\mathrm{N}$ removal rates higher than the non-aerated ones.

Many studies assume that dissimilatory reduction of $\mathrm{NO}_{3}{ }^{-}$to $\mathrm{NO}_{2}{ }^{-}$is an anaerobic process, but this first step of denitrification can occur in some bacteria even at high oxygen concentrations. ${ }^{[4-49]}$ Aerobic $\mathrm{NO}_{3}{ }^{-}$reduction occurs when provided with both $\mathrm{NO}_{3}{ }^{-}$and a carbon source, with a concomitant greatest $\mathrm{NO}_{2}{ }^{-}$accumulation at the wetlands. ${ }^{[48]}$ Nitrite is then converted to $\mathrm{NO}$ or $\mathrm{N}_{2} \mathrm{O}$ through nitrite reductase (Nir) being the nirK and nirS genes the most widely used molecular biomarkers employed to characterize the denitrifier communities. Bacteria harboring different denitrifying genes might be amplified or attenuated under different environmental conditions and consequentially change the profiles of denitrifying genes in different environments. In such sense, Nir expression in aerobic environments might be a common phenomenon. Accordingly, the improved in $\mathrm{NO}_{3}-\mathrm{N}$ removal efficiency observed for the cork and gravel aerated wetlands (i.e., VF3-CA and VF4GA) was correlated with a significantly higher $(p<0.05)$ relative abundance of the nirS gene (Figure 4). Therefore,

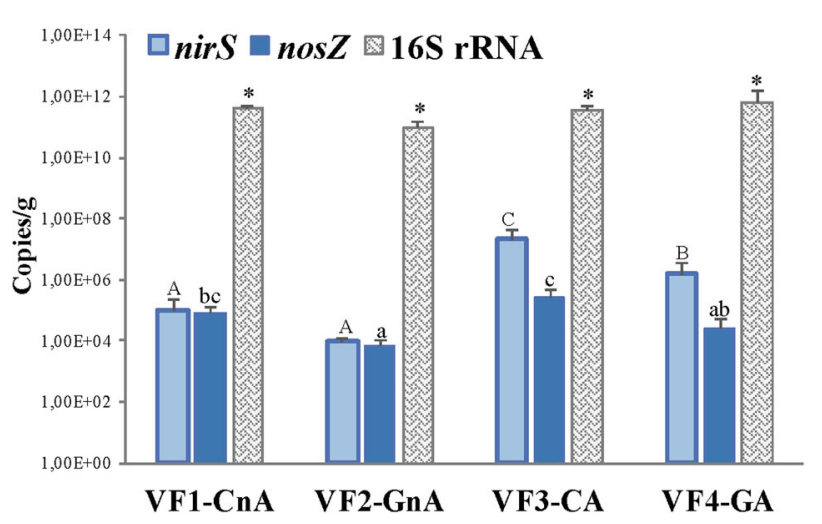

Figure 4. Copies number of nirS, nosZ and 16S rRNA genes for cork (C) and gravel (G) aerated (A) and non-aerated (nA) pilot-scale vertical flow (VF) treatment wetlands. Results are presented as mean \pm S.D at the last sampling campaign $(n=3)$. Data of sampling VFCW not sharing a common capital letter are statistically different for nirS abundance $(p<0.05)$; data of sampling VFCW not sharing a common lowercase letter are statistically different for nosZ abundance $(p<0.05) .{ }^{*}$, indicates no statistically significant differences between 16S rRNA gene copies number (used to assess bacterial load) at the different VFCW studied.

taken together, our results demonstrate that intermittent aeration facilitates $\mathrm{NO}_{3}{ }^{-}$reduction in VFCW and the subsequent $\mathrm{NO}_{2}^{-}$accumulation stimulate denitrifying microbes in the VF3-CA and VF4-GA biofilms.

Moreover, at the last sampling campaign, a slight improve in $\mathrm{NO}_{3}-\mathrm{N}$ removal was measured in the aerated cork wetland $(57.4 \pm 7.1 \%$ for VF3-CA) compared to gravel system (50.1 $\pm 6.3 \%$ for VF4-GA) (Table 5). Remarkedly, this fact was also correlated with a significative higher $(p<0.05)$ relative abundance of the nirS and nosZ genes in VF3-CA compared to VF4-GA (Figure 4), suggesting that the filter material had an influence on bacterial diversity. This result agrees with a previous work describing that the filter media played a significant role in structuring microbial assemblages in cork and gravel constructed wetlands aimed to nitrogen removal from polluted water. ${ }^{[14]}$

On the other hand, TN removal in the pilot-scale VFCW under study was not significantly improved by intermittent aeration (Figure 3). However, it is noteworthy that at the last sampling campaign both cork VFCW (i.e., VF1-CnA and VF3-CA) showed higher TN removal mean values $(\sim 35 \%)$ than the gravel wetland VF2-GnA $(26.9 \pm 9.5 \%)$ and VF4-GA $(28.3 \pm 5.1 \%)$, respectively. It is well known that heterotrophic denitrifiers require organic carbon for cell growth and as the electron donor in the denitrification process. $^{[1,27-29]}$ Cork is a chemically complex natural product mainly composed of suberin, lignin, waxes and polysaccharides (cellulose and hemicellulose), which are structural components, but also include some extractable compounds such as tannins. ${ }^{[13]}$ Therefore, the use of cork can provide an additional carbon source to stimulate denitrification and thus increase TN removal performance in cork wetlands. Further, cork by-products have been proposed as a great adsorbent material for organic pollutants, ${ }^{[12,14]}$ so it is possible that adsorption of some nitrogen-containing organic compounds to cork may occur, helping to improve TN removal performance within constructed wetlands filled with cork media compared to gravel media. 
The process of using solid carbon sources for nitrogen removal is called solid-phase denitrification. ${ }^{[50]}$ Natural and synthetic C-sources, such as woodchips, leaf compost, rice straw, polylactic acid and polybutylene succinate, have been used as solid carbon sources for different purposes. ${ }^{[43,51]}$ The solid carbon source used in TW must be insoluble and rather resistant to biodegradation. In addition, it is desirable that carbon sources for nitrogen removal in wastewaters have low cost, easy availability, and consistent characteristics and composition. Therefore, the use of cork by products as a carbon source for efficient nitrogen removal from wastewaters is a very attractive option.

Carbon sources not only act as electron donors but also as a substrate for biomass growth. Regarding this, and as previously stated the use of cork as a filter material in TW played a significant role in structuring microbial assemblages and in shaping bacterial diversity. Notably, at the present study cork VFCW showed a higher relative abundance of the nos $\mathrm{Z}$ gene (Figure 4) that codifies for a nitric oxide reductase involved in the final step of the denitrification. ${ }^{[22]}$ So, it is possible that the available carbon sources from cork can promote the long-term growth of different types of denitrifying bacteria and positively affect the presence of some denitrifying genes.

\section{Conclusions}

Cork and gravel VFCW were highly efficient to remove organic matter $(\geq 90 \%)$ once an active biofilm was settled along the systems' operation. Air introduction to the wetlands favored oxidative bioprocesses thus accelerating the bioremediation rates of the organic load, and to a lesser extent $\mathrm{NH}_{4}-\mathrm{N}$ removal. Induced aeration in VFCW was highly effective to improve $\mathrm{NO}_{3}-\mathrm{N}$ removal from wastewater, and this greater performance was correlated with an increased in the relative abundance of the nirS and nos $\mathrm{Z}$ genes indicative of an enhanced function of the denitrifying communities. Intermittent aeration and the contribution of organic carbon by the cork-layer filter material improved TN removal by allowing a greater growth of denitrifying bacteria within aerated compared to non-aerated and a better efficiency in the removal of nitrates with cork as a filtering medium compared to gravel. Therefore, the presented study underlines the importance of the correct choice of a carbon source which is both low-cost and well-suited for solid-phase denitrification and confirms our previous results proving the use of cork as alternative granular media for TW aimed for nitrogen removal from wastewater.

\section{Acknowledgements}

To LIFE Programme, the EU's financial instrument supporting environmental, nature conservation and climate action projects throughout the EU, that supports LIFE ECORKWASTE $14 \mathrm{ENV/ES/460.}$

\section{References}

[1] Yamashita, T.; Yamamoto-Ikemoto, R. Nitrogen and Phosphorus Removal from Wastewater Treatment Plant
Effluent via Bacterial Sulfate Reduction in an Anoxic Bioreactor Packed with Wood and Iron. Int. J. Environ. Res. Public Health 2014, 11, 9835-9853. DOI: 10.3390/ijerph110909835.

[2] Bamba, D.; Coulibaly, M.; Robert, D. Nitrogen-Containing Organic Compounds: Origins, Toxicity and Conditions of Their Photocatalytic Mineralization over $\mathrm{TiO}_{2}$. Sci. Total Environ. 2017, 580, 1489-1504. DOI: 10.1016/j.scitotenv.2016.12.130.

[3] Vymazal, J. Constructed Wetlands for Treatment of Industrial Wastewaters: A Review. Ecol. Eng. 2014, 73, 724-751. DOI: 10. 1021/es101403q.

[4] Dong, H.; Qiang, Z.; Li, T.; Jin, H.; Chen, W. Effect of Artificial Aeration on the Performance of Vertical-Flow Constructed Wetland Treating Heavily Polluted River Water. J. Environ. Sci. 2012, 24, 596-601. DOI: 10.1016/S1001-0742(11)60804-8.

[5] Vymazal, J. The Use of Hybrid Constructed Wetlands for Wastewater Treatment with Special Attention to Nitrogen Removal: A Review of a Recent Development. Water Res. 2013, 47, 4795-4811. DOI: 10.1016/j.watres.2013.05.029.

[6] Zou, J.; Guo, X.; Han, Y.; Liu, J.; Liang, H. Study of a Novel Vertical Flow Constructed Wetland System with Drop Aeration for Rural Wastewater Treatment. Water. Air. Soil Pollut. 2012, 223, 889-900. DOI: 10.1007/s11270-011-0910-x.

[7] Nivala, J.; Wallace, S.; Headley, T.; Kassa, K.; Brix, H.; Afferden, M.; Müller, R. Oxygen Transfer and Consumption in Subsurface Flow Treatment Wetlands. Ecol. Eng. 2013, 61, 544-554. DOI: 10.1016/j.ecoleng.2012.08.028.

[8] Stefanakis, A. I.; Tsihrintzis, V. A. Effects of Loading, Resting Period, Temperature, Porous Media, Vegetation and Aeration on Performance of Pilot-Scale Vertical Flow Constructed Wetlands. Chem. Eng. J. 2012, 181-182, 416-430. DOI: 10.1016/ j.cej.2011.11.108.

[9] Rous, V.; Vymazal, J.; Hnátková, T. Treatment Wetlands Aeration Efficiency: A Review. Ecol. Eng. 2019, 136, 62-67. DOI: $10.1016 /$ j.ecoleng.2019.06.006.

[10] Vymazal, J. Removal of Nutrients in Various Types of Constructed Wetlands. Sci. Total Environ. 2007, 380, 48-65. DOI: 10.1016/j.scitotenv.2006.09.014.

[11] Wu, H.; Zhang, J.; Ngo, H. H.; Guo, W.; Hu, Z.; Liang, S.; Fan, J.; Liu, H. A Review on the Sustainability of Constructed Wetlands for Wastewater Treatment: Design and Operation. Bioresour. Technol. 2015, 175, 594-601. DOI: 10.1016/j.biortech. 2014.10.068.

[12] Domingues, V.; Priolo, G.; Alves, A.; Cabral, M.; Delerue, C. Adsorption Behavior of Alpha -Cypermethrin on Cork and Activated Carbon . J. Environ. Sci. Health. B. 2007, 42, 649-654. DOI: 10.1080/03601230701465635.

[13] Machado, A. I.; Dordio, A.; Fragoso, R.; Leitao, A. E.; Duarte, E. Furosemide Removal in Constructed Wetlands: comparative Efficiency of LECA and Cork Granulates as Support Matrix. J. Environ. Manag. 2017, 203, 422-428. DOI: 10.1016/j.jenvman. 2017.08.002.

[14] Aguilar, L.; Gallegos, A.; Arias, C. A.; Ferrera, I.; Sánchez, O.; Rubio, R.; Saad, M. B.; Missagia, B.; Caro, P.; Sahuquillo, S.; et al. Microbial Nitrate Removal Efficiency in Groundwater Polluted from Agricultural Activities with Hybrid Cork Treatment Wetlands. Sci. Total Environ. 2019, 653, 723-734. DOI: 10.1016/j.scitotenv.2018.10.426.

[15] Fan, J.; Wang, W.; Zhang, B.; Guo, Y.; Ngo, H.; Guo, W.; Zhang, J.; Wu, H. Nitrogen Removal in Intermittently Aerated Vertical Flow Constructed Wetlands: Impact of Influent COD/ $\mathrm{N}$ Ratios. Bioresour. Technol. 2013, 143, 461-466. DOI: 10. 1016/j.biortech.2013.06.038.

[16] Fan, J.; Zhang, J.; Guo, W.; Liang, S.; Wu, H. Enhanced LongTerm Organics and Nitrogen Removal and Associated Microbial Community in Intermittently Aerated Subsurface Flow Constructed Wetlands. Bioresour. Technol. 2016, 214, 871-875. DOI: 10.1016/j.biortech.2016.05.083.

[17] Wu, H.; Fan, J.; Zhang, J.; Ngo, H.; Guo, W.; Hu, Z.; Lv, J. Optimization of Organics and Nitrogen Removal in Intermittently Aerated Vertical Flow Constructed Wetlands: 
Effects of Aeration Time and Aeration Rate. Int. Biodeter Biodegr. 2016, 113, 139-145. DOI: 10.1016/j.ibiod.2016.04.031.

[18] Zhou, X.; Gao, L.; Zhang, H.; Wu, H. Determination of the Optimal Aeration for Nitrogen Removal in Biochar-Amended Aerated Vertical Flow Constructed Wetlands. Bioresour. Technol. 2018, 261, 461-464. DOI: 10.1016/j.biortech.2018.04. 028.

[19] Hou, J.; Wang, X.; Wang, J.; Xia, L.; Zhang, Y.; Li, D.; Ma, X. Pathway Governing Nitrogen Removal in Artificially Aerated Constructed Wetlands: Impact of Aeration Mode and Influent Chemical Oxygen Demand to Nitrogen Ratios. Bioresour. Technol. 2018, 257, 137-146. DOI: 10.1016/j.biortech.2018.02. 042.

[20] Brix, H.; Arias, C. A. The Use of Vertical Flow Constructed Wetlands for on-Site Treatment of Domestic Wastewater: New Danish Guidelines. Ecol. Eng. 2005, 25, 491-500. DOI: 10.1016/ j.ecoleng.2005.07.009.

[21] Wang, X.; Tian, Y.; Zhao, X.; Peng, S.; Wu, Q.; Yan, L. Effects of Aeration Position on Organics, Nitrogen and Phosphorus Removal in Combined Oxidation Pond-Constructed Wetland Systems. Bioresour. Technol. 2015, 198, 7-15. DOI: 10.1016/j. biortech.2015.08.150.

[22] Chon, K.; Chang, J. S.; Lee, E.; Lee, J.; Ryu, J.; Cho, J. Abundance of Denitrifying Genes Coding for Nitrate (narG), Nitrite (nirS), and Nitrous Oxide (nosZ) Reductases in Estuarine versus Wastewater Effluent-Fed Constructed Wetlands. Ecol. Eng. 2011, 37, 64-69. DOI: 10.1016/j.ecoleng. 2009.04.005.

[23] Meng, P.; Pei, H.; Hu, W.; Shao, Y.; Li, Z. How to Increase Microbial Degradation in Constructed Wetlands: Influencing Factors and Improvement Measures. Bioresour. Technol. 2014, 157, 316-326. DOI: 10.1016/j.biortech.2014.01.095.

[24] Li, M.; Wu, H.; Zhang, J.; Ngo, H. H.; Guo, W.; Kong, Q. Nitrogen Removal and Nitrous Oxide Emission in Surface Flow Constructed Wetlands for Treating Sewage Treatment Plant Effluent: Effect of C/N Ratios. Bioresour. Technol. 2017, 240, 157-164. DOI: 10.1016/j.biortech.2017.02.054.

[25] Liu, L.; Zhao, X.; Zhao, N.; Shen, Z.; Wang, M.; Guo, Y.; Xu, Y. Effect of Aeration Modes and Influent COD/N Ratios on the Nitrogen Removal Performance of Vertical Flow Constructed Wetland. Ecol. Eng. 2013, 57, 10-16. DOI: 10.1016/j.ecoleng. 2013.04.019.

[26] Ilyas, H.; Masih, I. The Performance of the Intensified Constructed Wetlands for Organic Matter and Nitrogen Removal: A Review. J. Environ. Manag. 2017, 198, 372-383. https://doi.org/doi:10.1016/j.jenvman.2017.04.098.

[27] Saeed, T.; Sun, G. A Review on Nitrogen and Organics Removal Mechanisms in Subsurface Flow Constructed Wetlands: Dependency on Environmental Parameters, Operating Conditions and Supporting Media. J. Environ. Manag. 2012, 112, 429-448. DOI: 10.1016/j.jenvman.2012.08. 011.

[28] Fu, G.; Yu, T.; Ning, K.; Guo, Z.; Wong, M.-H. Effects of Nitrogen Removal Microbes and Partial NitrificationDenitrification in the Integrated Vertical-Flow Constructed Wetland. Ecol. Eng. 2016, 95, 83-89. https://doi.org/doi.org/10. 1016/j.ecoleng.2016.06.054. DOI: 10.1016/j.ecoleng.2016.06.054.

[29] Hang, Q.; Wang, H.; Chu, Z.; Ye, B.; Li, C.; Hou, Z. L. Application of Plant Carbon Source for Denitrification by Constructed Wetland and Bioreactor: review of Recent Development. Environ. Sci. Pollut. Res. Int. 2016, 23 8260-8274. DOI: 10.1007/s11356-016-6324-y.

[30] Bru, D.; Sarr, A.; Philippot, L. Relative Abundances of Proteobacterial Membrane-Bound and Periplasmic Nitrate Reductases in Selected Environments. Appl. Environ. Microbiol. 2007, 73, 5971-5974. DOI: 10.1128/AEM.00643-07.

[31] Braker, G.; Zhou, J. Z.; Wu, L. Y.; Devol, A. H.; Tiedje, J. M. Nitrite Reductase Genes (nirK and nirS) as Functional Markers to Investigate Diversity of Denitrifying Bacteria in Pacific Northwest Marine Sediment Communities. Appl. Environ.
Microbiol. 2000, 66, 2096-2104. DOI: 10.1128/AEM.66.5.20962104.2000.

[32] Sánchez, O. Constructed Wetlands Revisited: Microbial Diversity in the -omics Era. Microb. Ecol. 2017, 73, 722-733. https://doi.org/10.1007/s00248-016-0881. DOI: 10.1007/s00248016-0881-y.

[33] Nadeau, S. A.; Roco, C. A.; Debenport, S. J.; Anderson, T. R.; Hofmeister, K. L.; Walter, M. T.; Shapleigh, J. P. Metagenomic Analysis Reveals Distinct Patterns of Denitrification Gene Abundance across Soil Moisture, Nitrate Gradients. Environ. Microbiol. 2019, 21, 1255-1266. DOI: 10.1111/1462-2920.14587.

[34] Kadlec, R. H.; Wallace, S. D. Treatment Wetlands, 2nd ed.; CRC Press: Boca Raton, Florida, 2009.

[35] American Public Health Association (APHA). Standard Method for Examination of Water and Wastewater, 21st ed.; APHA, AWWA, WPCF: Washington, 2012.

[36] Adrados, B.; Sánchez, O.; Arias, C. A.; Becares, E.; Garrido, L.; Mas, J.; Brix, H.; Morató, J. Microbial Communities from Different Types of Natural Wastewater Treatment Systems: Vertical and Horizontal Flow Constructed Wetlands and Biofilters. Water Res. 2014, 55, 304-312. DOI: 10.1016/j.watres. 2014.02.011.

[37] Pérez, L. M.; Fittipaldi, M.; Adrados, B.; Morató, J.; Codony, F. Error Estimation in Environmental DNA Targets Quantification Due to PCR Efficiencies Differences between Real Samples and Standards. Folia Microbiol. (Praha) 2013, 58, 657-662. DOI: 10. 1007/s12223-013-0255-5.

[38] Mota, C.; Head, M. A.; Ridenoure, J. A.; Cheng, J. J.; de Los Reyes, F. L. de Los Reyes, F. Effects of Aeration Cycles on Nitrifying Bacterial Populations and Nitrogen Removal in Intermittently Aerated Reactors. Appl. Environ. Microbiol. 2005, 71, 8565-8572. DOI: 10.1128/AEM.71.12.8565-8572.2005.

[39] Rodriguez-Caballero, A.; Ribera, A.; Balcázar, J. L.; Pijuan, M. Nitritation versus Full Nitrification of Ammonium-Rich Wastewater: Comparison in Terms of Nitrous and Nitric Oxides Emissions. Bioresour. Technol. 2013, 139, 195-202. DOI: 10.1016/j.biortech.2013.04.021.

[40] Vacca, G.; Wand, H.; Nikolausz, M.; Kuschk, P.; Kästner, M. Effect of Plants and Filter materials on bacteria removal in pilot-scale constructed wetlands . Water Res. 2005, 39, 1361-1373. DOI: 10.1016/j.watres.2005.01.005.

[41] Calheiros, C. S. C.; Duque, A. F.; Moura, A.; Henriques, I. S.; Correia, A.; Rangel, A. O. S. S.; Castro, P. M. L. Substrate Effect on Bacterial Communities from Constructed Wetlands Planted with Typha Latifolia Treating Industrial Wastewater. Ecol. Eng. 2009, 35, 744-753. DOI: 10.1016/j.ecoleng.2008.11. 010 .

[42] Li, M.; Zhou, Q.; Tao, M.; Wang, Y.; Jiang, L.; Wu, Z Comparative Study of Microbial Community Structure in Different Filter Media of Constructed Wetland. J. Environ. Sci. 2010, 22, 127-133. DOI: 10.1016/S1001-0742(09)60083-8.

[43] Rajta, A.; Bhatia, R.; Setia, H.; Pathania, P. Role of Heterotrophic Aerobic Denitrifying Bacteria in Nitrate Removal from Wastewater. J. Appl. Microbiol. 2020, 128, 1261-1278. DOI: $10.1111 /$ jam.14476.

[44] Princic, A.; Mahne, I.; Megusar, F.; Paul, E. A.; Tiedje, J. M. Effects of $\mathrm{pH}$ and Oxygen and Ammonium Concentrations on the Community Structure of Nitrifying Bacteria from Wastewater. Appl. Environ. Microbiol. 1998, 64, 3584-3590. DOI: 10.1128/AEM.64.10.3584-3590.1998.

[45] Bellucci, M.; Ofiteru, I. D.; Graham, D. W.; Head, I. M.; Curtis, T. P. Low-Dissolved-Oxygen Nitrifying Systems Exploit Ammonia-Oxidizing Bacteria with Unusually High Yields. Appl. Environ. Microbiol. 2011, 77, 7787-7796. DOI: 10.1128/AEM. 00330-11.

[46] Bock, E.; Schmidt, I.; Stüven, R.; Zart, D. Nitrogen Loss Caused by Denitrifying Nitrosomonas Cells Using Ammonium or Hydrogen as Electron Donors and Nitrite as Electron Acceptor. Arch. Microbiol. 1995, 163, 16-20. DOI: 10.1007/BF00262198. 
[47] Ji, B.; Yang, K.; Zhu, L.; Jiang, Y.; Wang, H.; Zhou, J.; Zhang, H. Aerobic Denitrification: A Review of Important Advances of the Last 30 Years. Biotechnol. Bioproc. E. 2015, 20, 643-651. DOI: 10.1007/s12257-015-0009-0.

[48] Roco, C. A.; Bergaust, L. L.; Shapleigh, J. P.; Yavitt, J. B. Reduction of Nitrate to Nitrite by Microbes under Oxic Conditions. Soil Biol. Biochem. 2016, 100, 1-8. DOI: 10.1016/j. soilbio.2016.05.008

[49] Zhang, S.; Pang, S.; Wang, P.; Wang, C.; Guo, C.; Addo, F. G.; $\mathrm{Li}$, Y. Responses of Bacterial Community Structure and
Denitrifying Bacteria in Biofilm to Submerged Macrophytes and Nitrate. Sci. Rep. 2016, 6, 36178. DOI: 10.1038/srep36178.

[50] Ashok, V.; Hait, S. Remediation of Nitrate-Contaminated Water by Solid-Phase Denitrification Process-A Review . Environ. Sci. Pollut. Res. Int. 2015, 22, 8075-8093. DOI: 10.1007/s11356-015-4334-9.

[51] Ruan, Y. J.; Deng, Y. L.; Guo, X. S.; Timmons, M. B.; Lu, H. F.; Han, Z. Y.; Ye, Z. Y.; Shi, M. M.; Zhu, S. M. Simultaneous Ammonia and Nitrate Removal in an Airlift Reactor Using poly(butylene succinate) as carbon source and biofilm carrier. Bioresour. Technol. 2016, 216, 1004-1013. DOI: 10.1016/j.biortech.2016.06.056. 